\title{
Services procurement under the WTO's Agreement on Government Procurement: Whither market access?
}

\begin{abstract}
Anirudh Shingal ${ }^{1}$
Abstract

This paper studies the government procurement of services from foreign suppliers by conducting a statistical analysis of data submitted by Japan and Switzerland to the WTO's Committee on Government Procurement. Using several metrics, the paper examines if the WTO's Agreement on Government Procurement (GPA) has led to greater market access for foreign suppliers in services procurement. Our results indicate that despite the GPA, the proportions of services contracts awarded to foreigners have declined over time for both countries and in the absence of this decline, the value of services contracts awarded to foreign firms would have been more than 15 times higher in the case of Japan and nearly 68 times more in the case of Switzerland. We also find that for the same services categories, at least the Japanese government is not purchasing as much from abroad as it's private sector is importing from the rest of the world, a finding that further points to the home-bias in that government's public purchase decisions.
\end{abstract}

Key words: Services, public procurement, GPA, Japan, Switzerland

JEL classification: F10, F13, H57

${ }^{1}$ Senior Research Fellow, WTI, University of Bern \& Research Affiliate, CARIS, University of Sussex. I would like to thank Prof. Alan Winters and two anonymous referees for their useful comments. The usual disclaimer applies. Address for correspondence: World Trade Institute, Hallerstrasse 6, $\mathrm{CH}$ 3012, Bern; Email: anirudh.shingal@wti.org.

\section{FNDNF}

FONDS NATIONAL SUISSE ALE SVIZZERO SWISS NATIONAL SCIENCE FOUNDATION
Die Nationalen Forschungsschwerpunkte (NFS) sind ein Förderinstrument des Schweizerischen Nationalfonds. Les Pôles de recherche nationaux (PRN) sont un instrument d'encouragement du Fonds national suisse.

The National Centres of Competence in Research (NCCR) are a research instrument of the Swiss National Science Fondation. 


\section{Table of Contents}

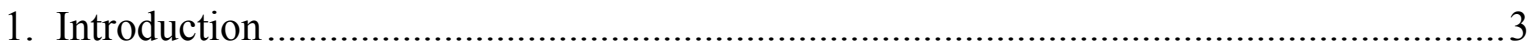

2. The GPA and foreign procurement of services.......................................................

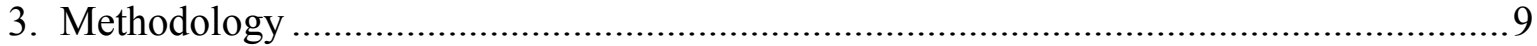

4. Analyses of Country Services Procurement Patterns................................................. 13

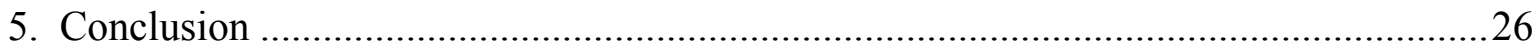

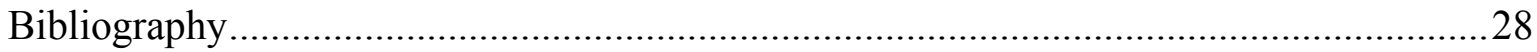

\section{List of figures and tables}

Figure 1: A Snapshot of Country Procurement Patterns .............................................. 14

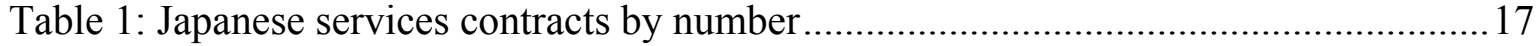

Table 2: Japanese services contracts by value ......................................................... 18

Table 3: Swiss services contracts by number...........................................................21

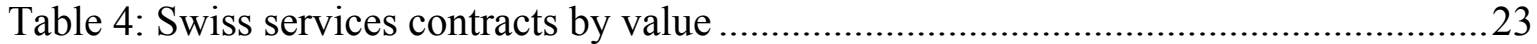

Table 5: Private-public purchase differentials ...................................................... 24

Annex Table 1: Statistical submissions made to the Committee on Government

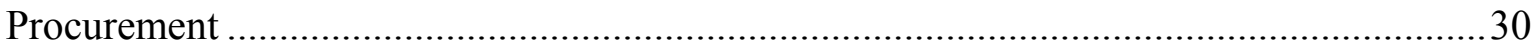

Annex Table 2: List of services procured by the Japanese ........................................... 31

Annex Table 3: List of services procured by the Swiss ...............................................32 


\section{Introduction}

The rise in total spending by central and local governments was one of the most profound economic changes of the twentieth century (S.J. Evenett, 2000). This is consistent with Public Finance theory as propounded by Wagner and Baumol - an increase in GDP is accompanied by an increasing role of the state in maintaining law and order, providing essential services like education and health and contributing to other significant economic activities. This also means that the government in its various forms - central and sub-central as well as state-owned enterprises - spends a considerable sum of money on procuring goods and services in keeping with its growing responsibilities. Typically, figures for government procurement range from 10 to 15 per cent of GDP across countries. A study by the OECD (2002) estimates that government procurement (inclusive of defence and compensation of employees) accounts for almost 20 per cent of GDP in OECD countries and between 9 and 20 per cent of GDP in developing countries. An immediate implication is that through procurement, the state has influence over the allocation of resources in market economies. Another interesting observation in this regard is the preponderance of domestic suppliers meeting the procurement requirements of governments throughout much of the post-World War II period, possibly suggesting the use of public procurement as a non-tariff barrier to trade.

Minimizing procurement costs is not the only argument in the government's objective function. Governments are also saddled with political economy considerations and other non-economic objectives like the promotion of domestic industry, encouraging the transfer of technology, promoting small, medium and artisan firms and state enterprises, and the promotion of national security. This means that goods and services may not always be bought from the most costeffective or efficient supplier, in effect making discrimination in public procurement inevitable. In fact, procurement literature has used the theory of auctions and asymmetric information to develop models that show that discrimination may be necessary to minimize average procurement costs ${ }^{2}$.

\footnotetext{
${ }^{2}$ For instance see McAfee \& McMillan (1989), Laffont \& Tirole (1991), Rothenberg (1993), Branco (1994), Breton \& Salmon (1995) and Chen (1995).
} 
However, even if discrimination is an optimal policy outcome, the net welfare benefits are likely to be modest at best. Rather, the cost savings for procuring entities and greater profits for domestic firms that favouritism generates will be offset by increased average prices (Deltas and Evenett, 1997). In any case, the optimal discriminating mechanism is specific to the underlying conditions and even small deviations can eliminate any gains. On the other hand, studies have shown that cost savings through competitive bidding are in the range of $30 \%$ (Transparency International, 1997; World Bank, 1994).

This argument in favour of non-discrimination is the cornerstone on which most disciplines on government procurement are formulated. These measures include efforts undertaken by the EC as a part of its internal market reform and deregulation programmes, disciplines already present and those being negotiated in various preferential trade agreements, and the non-binding proposals of the APEC and the UNCITRAL Model Law (United Nations Commission on International Trade Law). Arguably, the most important of such initiatives has been the WTO's plurilateral Agreement on Government Procurement (GPA).

In this paper, we examine whether the GPA has been able to increase non-discriminatory procurement by looking at the pattern of public purchases in two countries - Japan and Switzerland - since the implementation of the Uruguay Round GPA (URGPA). The choice of countries in this analysis was primarily determined by data availability considerations. Both countries submitted detailed procurement data consistently since the URGPA, in a form that was amenable to the statistical analysis undertaken in this paper. But there were other considerations as well: both are large open services-intensive economies (services account for $75 \%$ of GDP) and both have large governments, federal and sub-federal (average share of total government expenditure in GDP over 1996-2002 was almost 50\% in Japan and 37\% in Switzerland).

Data on government procurement was assembled from these countries' submission to the WTO's Committee on Government Procurement. Shingal (2002) and Evenett and Shingal (2006) analyzed this data in the case of Japan and found that the compliance mechanisms of the GPA "failed to prevent reductions in foreign penetration to Japan's state procurement 
markets ${ }^{3}$." The analysis was undertaken for both goods and services contracts awarded up to 1999 and concluded that "the proportion of total contracts awarded to foreigners in 1998 and 1999 was lower than in 1990 and 1991. In the absence of these changes, the value of contracts awarded to foreign firms would have been approximately 25 percent higher in 1998 and $1999^{4}$." In this paper, we build on this earlier work by developing new metrics, extending the period of analysis and focusing exclusively on services procurement.

Our results indicate that, at least for these two countries, foreign market access in services procurement has not increased through the 1990s since the coming into effect of the GPA. In fact, the proportions of services contracts awarded to foreigners have declined over 1996/97$2002 / 03$ for both countries and in the absence of this decline, the value of services contracts awarded to foreign firms would have been more than 15 times higher in the case of Japan and nearly 68 times more in the case of Switzerland! We also find that for the same services categories, the Japanese government is not purchasing as much from abroad as it's private sector is importing from the rest of the world, a finding that further points to the home-bias in that government's public purchase decisions.

The structure of the paper is as follows. Section 2 discusses the GPA, including the scope of the Agreement and the availability of data that forms the basis of the analysis in the paper. Section 3 looks at the methodology employed while Section 4 analyzes the individual country procurement patterns of the two countries in our sample and discusses the evolution of counterfactuals over time and in comparison with the private sector. Section 5 concludes.

\section{The GPA and foreign procurement of services}

2.1. The background: The GPA is a plurilateral agreement that was first negotiated during the Tokyo Round of Multilateral Trade Negotiations (1973-79) and came into effect on January 1, 1981. A 1987 Protocol amended the Tokyo Round Procurement Code and the new version entered into force on January 1, 1988. The GPA, as it stands today, was

\footnotetext{
${ }^{3}$ Evenett and Shingal (2006), op.cit, pp1.

${ }^{4}$ Evenett and Shingal (2006), op.cit, pp1.
} 
negotiated in parallel with the Uruguay Round of the GATT and came into effect on January 1, 1996. The URGPA has 40 Contracting Parties as its signatories ${ }^{5}$. Article XIX: 5 of the GPA requires that all Contracting Parties report data on procurement by government entities to the Committee on Government Procurement. This data pertains to the value and the number of contracts awarded by government procuring entities to winning suppliers who bid for them through one of the three procurement practices outlined in the Agreement - open tendering, selective tendering and limited tendering. The GPA requires that only procurement above a certain threshold value be subject to international competitive bidding.

\section{2. Scope and Coverage of the Agreement: The GPA does not apply to all} government procurement undertaken by its Contracting Parties. The Annexes of the GPA outline government entities and purchases of goods and services that are potentially disciplined by the Agreement. The GPA applies only to entities ${ }^{6}$ listed in Appendix 1 of the Agreement. This contains five Annexes for each signatory. Annex 1 lists covered central government entities; Annex 2 lists sub-central government entities; and Annex 3 is a "catch-all" category that lists all other entities (such as utilities) that procure in accordance with the provisions of the GPA. Annex 4 lists covered services, and Annex 5 covered construction services. In addition, the URGPA's requirement of international competitive bidding does not apply to all procurement by the covered entities. Coverage depends on whether the value of the procurement is at or above a certain threshold.

Thresholds differ depending on the type of procurement and on the level of government making the purchase and are stated in terms of the IMF's accounting unit, the SDR. For Annex \#1 central government entities, the threshold values are SDR 130,000 for procurement of goods and services and SDR 5 million for procurement of construction services. For Annex \#2 sub-

\footnotetext{
${ }^{5}$ This list includes Canada, the European Community and its 27 constituents, Hong Kong, Iceland, Israel, Japan, Liechtenstein, Norway, Singapore, South Korea, Switzerland, Taiwan and the United States. In addition, Albania, Armenia, China, Georgia, Jordan, the Kyrgyz Republic, Moldova, Oman and Panama are in the process of negotiating their accession to the GPA. The list primarily comprises developed countries with Australia and New Zealand being notable exceptions; most developing and all LDCs have chosen not to be a part of the GPA.

${ }^{6}$ Interestingly, the term 'entity' is not defined anywhere in the GPA, thus reflecting the absence of consensus on what constitutes a public undertaking or entity as well as paving the way for discretion on the part of Contracting Parties in meeting their commitments under the Agreement.
} 
central government entities, the thresholds are SDR 200,000 for goods and services, (except for the United States and Canada which apply a SDR 355,000 threshold) and SDR 5 million for construction services (with the exception of Japan and the South Korea, which apply a SDR 15 million threshold). For Annex \#3 entities, the threshold values are SDR 400,000 for goods and services (with the exception that the United States applies a US\$ 250,000 threshold for federally owned utilities) and SDR 5 million for construction services (barring Japan and Korea, which apply a threshold of SDR 15 million). Additionally, the General Notes of individual signatories may specify higher thresholds for particular Contracting Parties in a bid to ensure reciprocity. ${ }^{7}$ Exceptions from the obligations of the Agreement are allowed for developing countries in certain situations outlined in Article V of the URGPA while general exceptions are contained in Article XXIII ${ }^{8}$.

2. 3. Data and its availability: Statistics submitted by the signatories to the WTO Secretariat are the primary source of data. Article XIX: 5 of the GPA requires that Contracting Parties submit procurement-related data to the Committee on Government Procurement. Article XIX:5(a) of the URGPA requires the submission of information on the value of contracts awarded both above and below the threshold. Article XIX:5(b) requires data on procurement above the threshold to be classified by procuring entities and by goods and services according to the nationality of the winning supplier irrespective of whether the supplier is located in a Contracting Party to the GPA. Data also needs to be provided on the use of limited tendering practices broken down by entity and by categories of goods and services (Article XIX:5(c)) and on derogations from the principles of Most Favoured Nation and National Treatment (Article XIX:5(d)).

Unfortunately, only half of the 40 Contracting Parties (Canada, EU-15, Japan, Norway, Switzerland, Hong Kong and the United States) have made statistical submissions since the

\footnotetext{
${ }^{7}$ The threshold can be different for different participants in the bid as is the case with the US' commitments on the procurement of construction services by Annex $2 \& 3$ entities vis-a-vis Korean suppliers. The threshold specified for construction services for Annex 2 and 3 entities in the US' government procurement commitments is SDR 5 million, but for Korean construction services and their suppliers, the US has set a higher threshold at SDR 15 million.

${ }^{8}$ According to this article, these measures should not be applied in a manner that would constitute a means of arbitrary or unjustifiable discrimination between countries where similar conditions prevail or a disguised restriction on international trade.
} 
URGPA came into being (details provided in Annex Table 1) ${ }^{9}$ and with the exception of Hong Kong, these submissions have been made electronically since $1997 .{ }^{10}$ Even amongst these, there are significant differences, both in terms of what is included and how it is included, and the need for consistency, has thus determined the choice of sample countries for the analysis that follows. ${ }^{11}$ A point to note here is the seriousness with which Contracting Parties to the GPA have met their commitments under Article XIX: 5, with half of the membership not making any information at all available in this regard. In the absence of any enforcement mechanism related to data requirements or any punitive action/public censure for nonsubmission, Contracting Parties seem not to have taken their responsibilities in this regard seriously. Submitting data on procurement is one of the best ways of ensuring transparency in public procurement and highlighting any break in trend in public purchase decisions that signals discrimination.

One problem in making inter-temporal comparisons is that different procurement codes were applicable in different time periods and these necessitated different data requirements. For instance, the Tokyo Round procurement code did not require data to be reported on the value and number of contracts awarded under derogations to the GPA. Furthermore, prior to the Uruguay Round procurement code, the scope of the GPA was limited to goods alone and to those services that were incidental to the procurement of such goods. With the Uruguay Round, the scope of the GPA was expanded to explicitly incorporate services (including construction services) and as such, data from before 1996 refers to goods alone while that post-1996 involves both goods and services. This imposes an additional challenge in the analysis of services procurement ${ }^{12}$.

\footnotetext{
${ }^{9}$ Data on government procurement is also available for certain years from 1981 onwards for Austria, Sweden, Finland (before they became Members of the EC), Singapore, Israel, and the European Communities. One standard observation is that submissions were not as detailed in the 1980s as they have been since the 1990s. Moreover, since 1997, Hong Kong, Japan and Norway have submitted this data almost every year.

${ }^{10}$ The US and Switzerland did this for 1996 as well.

${ }^{11}$ For instance, Japan has not submitted data for the years 1994-96 and 2005. The US did not make a submission in 1992, 1994, 1995, 2003, 2004 or 2006. Switzerland has not provided data for the year 1992 and beyond 2003.

12 As noted above, the GPA requires that Contracting Parties submit data on the number and value of contracts awarded both above and below the threshold. However, while the above threshold figures need to be classified as goods or services, below the threshold no breakdown is required. This means that it becomes difficult to examine how goods or services contracts awarded above threshold have changed as a proportion of total goods or total services contracts, as the case may be.
} 


\section{Methodology}

Two major potential benefits for GPA signatories emanate from the transparency requirements and the competition that results in the tax-paying public receiving better value for money spent by the government on its procurement activities, and from an increase in market access consequent upon purchases by governments of other Contracting Parties. In what follows, we examine if the latter objective has been fulfilled by undertaking an economic analysis of the statistical submissions. The methodology essentially involves building counterfactuals, one against time, and the other against the private sector.

For the purpose of these counterfactuals, we define the following metrics:

- $\quad$ Value of above-threshold (AT) contracts as a proportion of all contracts

- Value of contracts awarded to foreigners (FP) as a proportion of total abovethreshold contracts

- Value of contracts awarded using non-limited tendering (Non-LT) methods as a proportion of total above-threshold contracts ${ }^{13}$

These metrics give an idea of how governments might be using their procurement practices to restrict market access. Governments can, for instance, split contracts to keep them below thresholds and this would be reflected in the declining share of AT contracts in total procurement. Governments may also choose to award fewer contracts to foreign suppliers or to award them mostly by limited tendering methods, which would limit the size of procurement open to international competition. Thus, the value of contracts above threshold awarded using non-limited tendering methods would serve as a measure of international competition in procurement or an indicator of the volume of procurement subject to international competitive bidding (ICB). This would be a measure of the de jure openness in procurement markets. On the other hand, the value of contracts above threshold actually awarded to foreigners would measure the actual extent of foreign procurement (FP) and reflect the de facto openness in procurement markets.

\footnotetext{
${ }^{13}$ Contract data is not further disaggregated into selective tendering procedures to enable additional counterfactual analysis by this metric.
} 
To develop the counterfactual against time, we calculate the potential value of contracts in period ' $t$ ' by multiplying the actual value of contracts in period ' $t$ ' by a metric in period ' $t-1$.' If the metric in period ' $t-1$ ' was greater than that in period 't,' which would be the case with metrics that declined over time, the potential value would exceed the actual value and the difference can be read as the unrealized market access associated with that metric.

We thus define:

$U F P_{i t}=\left(f p_{i t-1}-f p_{i t}\right) * A T_{i t}$

where

$\mathrm{UFP}_{\mathrm{it}}=$ Unrealized foreign market access in the " $\mathrm{i}$ ", "th service category in year " $\mathrm{t}$ "

$\mathrm{fp}_{\mathrm{it}-1}=$ Share of foreign procurement in above-threshold procurement in the "i, th service category in year "t-1"

$\mathrm{fp}_{\mathrm{it}}=$ Share of foreign procurement in above-threshold procurement in the "i" " th service category in year " $\mathrm{t}$ "

$\mathrm{AT}_{\mathrm{it}}=$ Value of above-threshold procurement in the " $\mathrm{i}$ ", th service category in year " $\mathrm{t}$ "

And,

$U I C B_{i t}=\left(n o n L T_{i t-1}-n o n L T_{i t}\right) * A T_{i t}$

where

$\mathrm{UICB}_{\mathrm{it}}=$ Unrealized internationally competitive bidding in the " $\mathrm{i}$ ",th service category in year " $\mathrm{t}$ " nonLT $_{\text {it-1 }}=$ Share of non-limited tender contracts by value in above-threshold procurement in the " $i$ ", sh service category in year " $t-1$ "

nonLT $_{i t}=$ Share of non-limited tender contracts by value in above-threshold procurement in the "i" $\mathrm{p}$ "th service category in year " $\mathrm{t}$ "

$\mathrm{AT}_{\mathrm{it}}=$ Value of above-threshold procurement in the " $\mathrm{i}$ ", service category in year " $\mathrm{t}$ " 
One limitation of this methodology ${ }^{14}$, however, is that it holds as constant all other factors that may be responsible for a decline in the metrics. A change in domestic or foreign production structures, for instance, could lead to a re-orientation towards domestic suppliers. The change could also be dictated by macroeconomic factors such as a recession or by reasons of political economy such as governments being in an election cycle. If we could hold all these other factors constant, however, procurement would be characterized by declining metrics over time only if governments chose to restrict market access on purpose; constancy or an increase in these metrics on the other hand would therefore suggest that the converse was true. Since we cannot make such corrections, our results must be considered more as suggestive than conclusive and one would need empirical analysis to investigate the determinants of governments' procurement decisions. Thus, it may well be the case that the potential role of the GPA in increasing or even sustaining foreign market access may be limited even if commitments are taken seriously and foreign firms also maintain their interest in the market over time. This said, as we shall see below, the counterfactuals from our analyses are large enough in magnitude to suggest that the disciplines of the GPA have not been a binding constraint in ensuring non-discrimination in the award of services contracts.

Another way of illustrating any home-bias in government procurement is by comparing import intensities in the public and private sectors for the same services categories. The theoretical justification for this comparison is provided by Baldwin $(1970,1984)$ who shows that in a Hecksher-Ohlin model with a home-bias in government procurement, the reduction in imports from the government is compensated by a corresponding increase in the imports of the private sector $^{15}$. For the second counterfactual, therefore, the comparator used is the private sector and the intuition also involves simulating the effect of private-sector decision-making in public

\footnotetext{
${ }^{14}$ Another implicit assumption in this methodology is with respect to the choice of the base period. Given that our methodology attempts to carry out an ex-post impact assessment of the GPA in terms of market access, the base period should ideally predate the coming into effect of the GPA. However, since we only consider market access in services in this paper and the coverage of services in the GPA only began with the URGPA, the second best alternative is to consider as base a period just after the URGPA came into effect as market access in this initial period is unlikely to be affected by the disciplining mechanisms of the GPA. The use of our methodology is thus also based on the premise that by the later years of our sample period, the disciplining mechanisms of the GPA would have had a positive impact on market access in services procurement.

${ }^{15}$ Miyagawa (1991) extends Baldwin's “neutrality proposition” to an oligopolistic model.
} 
purchase decisions. Given that private sector efficiency is a benchmark for most governments, such a comparison becomes further appropriate.

While constructing this counterfactual, we assume that all other variables that have a bearing on public and private purchase decisions remain constant or affect these decisions identically. We simulate the effect of private-sector decision-making in public procurement decisions by using private sector import intensities in the share of total government procurement in each service category which is above-threshold and hence, potentially subject to ICB. This provides an estimate of the "foreign procurement" in each service category which would have been "undertaken" by the private sector had it been making government procuring decisions. From this we subtract the actual value of the foreign procurement undertaken by the government in each service category to get the size of the differential, which is termed as the Private-Public Purchase Differential (PPPD).

We thus define:

$P P P D_{i t}=\left[\left(\frac{M}{\operatorname{Pr} o d}\right)_{i t} *\left(\frac{A T_{i t}}{\sum_{i} A T_{i t}} * T o t \operatorname{Pr} o c_{t}\right)\right]-F P_{i t}$

where

$\mathrm{PPPD}_{\mathrm{it}}=$ Private-public purchase differential in the "i"th service category in year " $\mathrm{t}$ " $(\mathrm{M} / \text { Prod })_{\text {it }}=$ Ratio of imports to gross output in the "i,"th service category in year " $\mathrm{t}$ " TotProc $_{\mathrm{t}}=$ Value of total procurement in year " $\mathrm{t}$ " $\mathrm{AT}_{\mathrm{it}}=$ Value of above-threshold procurement in the " $\mathrm{i}$ ", ,th service category in year " $\mathrm{t}$ " $\sum \mathrm{AT}_{\mathrm{it}}=$ Value of total above-threshold procurement in year " $\mathrm{t}$ " $\mathrm{FP}_{\mathrm{it}}=$ Value of foreign procurement in the "i" $\mathrm{p}$ "th service category in year " $\mathrm{t}$ "

A positive PPPD in any service category implies that private sector imports in that service category exceed the amount of foreign procurement in it, which suggests a home-bias in 
government procurement. A negative PPPD on the other hand suggests that the converse may be true.

\section{Analyses of Country Services Procurement Patterns}

Figure 1 provides a snapshot of the procurement patterns in Japan and Switzerland over the period 1997-2003. The AT/Total (above- \& below-threshold) procurement shares are low in both countries (averaging 33\% in Japan and 27.5\% in Switzerland), which, prima facie, constricts the contestable procurement market in both countries. While these shares have fallen over time in Japan, Switzerland shows more fluctuations and a virtual reversion in 2003 to the 1997 share. Focusing on services procured above threshold, these average more than $60 \%$ of total AT procurement in both countries and these shares have also risen over time. However as a share of total above- $\&$ below-threshold procurement, the shares of services procured above threshold are much lower in both countries and less than $20 \%$ in the case of Switzerland. The shares of Non-LT in AT services procurement have been high in both countries, averaging $70 \%$ in Japan and $80 \%$ in Switzerland, but these have also fallen over time in both countries, and more considerably in the case of Switzerland from 86 to $68 \%$. Thus, for both these countries, prima facie, the share of the market open to unimpeded international competition has shrunk. The share of foreign procurement in AT services procurement has been very low in Japan, averaging 1.4\% over 1997-2003, and relatively higher in Switzerland with an average of $4.4 \%$ over 1997-2002, without showing huge fluctuations around this mean. However, the Swiss share jumped to $33.4 \%$ in 2003 as several high value contracts were awarded to foreign firms in technical, scientific and consulting services (category 14), a single category that accounts for more than half of all services procured above-threshold by Switzerland. In fact, if we exclude this category, then the share of foreign procurement in services purchased by Swiss central government entities would be close to the 4.4\% mean again. Unfortunately, 2003 is the last year for which data on government procurement is available in the case of Switzerland and it is therefore not possible to know if it signals a change in the trend of Swiss services procurement. We therefore regard the year as an outlier in our statistical analyses of Swiss services procurement. 
Figure 1: A Snapshot of Country Procurement Patterns

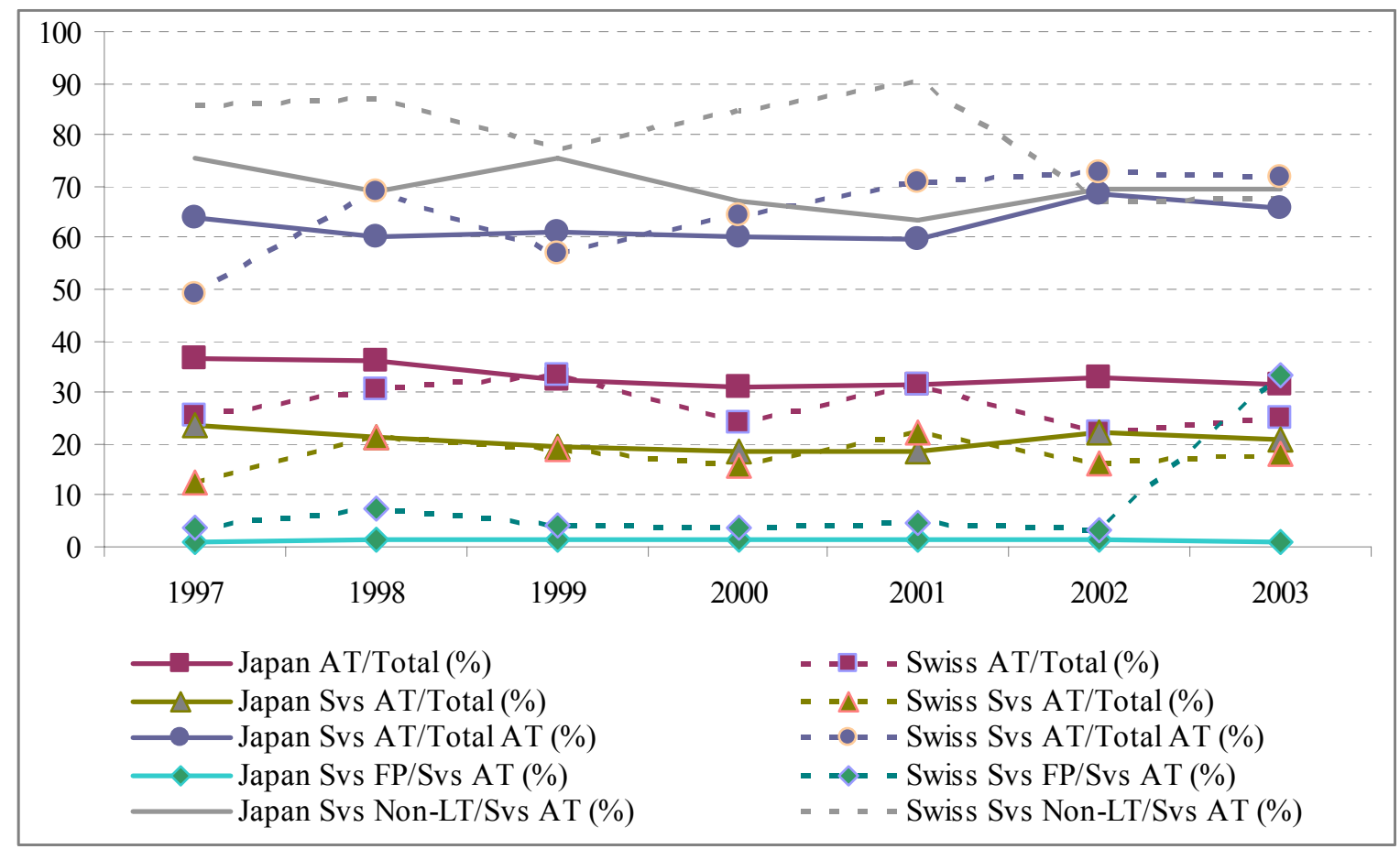

Source: WTO, Committee on Government Procurement; own calculations

\subsection{Japanese services procurement}

We begin by looking at Japanese submissions on services procurement averaged over 1997-98 and 2002-03 and compare both the percentage number and value of contracts awarded to foreign firms as well as those awarded using non-limited tendering methods during these periods in Tables 1 and 2. We consider all services, including construction, included by Japan in Annexes 4 and 5 of Appendix 1 of the GPA; the list is provided in Annex Table 2 of this paper.

Table 1 reports for 1997-98 and for 2002-03 the average number of services contracts that were awarded above-the-threshold, the number of these contracts that were awarded to foreign bidders, and the number of above-the-threshold contracts where limited tendering procedures were not used. Columns VIII and IX of this table report the proportion of contracts awarded to foreigners in 1997-98, 2002-03 and columns XI and XII report the proportion of contracts 
awarded in the same years without resort to limited tendering procedures. Finally, Columns $\mathrm{X}$ and XIII, respectively, report the results from statistically testing for each service category if the proportion of contracts awarded to foreigners in 1997-98 was the same as that in 2002-03 and if the proportion of above-the-threshold contracts that did not involve the use of limited tendering in 1997-98 was the same as that in 2002-03 ${ }^{16}$. While carrying out these tests, we weighted the proportions for each service category in the two time periods by the share of that category in the total value of contracts awarded in the respective time periods. Weighting the contract numbers by their values in this way becomes necessary because, as we shall see below, procurement in certain services dominates total above-threshold services procurement in these two countries.

In 1997-98, there were, on average, 2180.5 services contracts awarded above the threshold, of which 3.4\% were awarded to foreign firms. Sixty per cent of these contracts did not involve the use of limited tendering procedures. In 2002-03, the average number of contracts had risen to 3007.5 , the percentage awarded to foreigners had fallen marginally to $3.2 \%$, and the percentage of these contracts that did not employ limited tendering was lower at 58\%. Ceteris paribus, these findings are not indicative of greater foreign access to Japanese services procurement. However, the test statistic in the bottom line of Table 1 under column $\mathrm{X}$ takes the value of 0.69 , thereby failing to reject the hypothesis that the true probability of a contract being awarded to a foreign firm was no lower in 2002-03 than in 1997-98. Having said that, column $\mathrm{X}$ of Table 1 reveals that at least one services category (41, which is construction services), saw statistically significant reductions in the proportion of contracts awarded to foreign firms (albeit at the 10\% level) and this category accounted for $18.6 \%$ of all services contracts awarded by number and $78 \%$ of all services contracts awarded by value during 2002-03.

The final column of Table 1 reports the test statistic for the maximum proportion of purchases in each services category that are subject to internationally competitive bidding. Once again, in

\footnotetext{
${ }^{16}$ Formally, a one tail test is being performed here on two computed proportions. The null hypothesis is that the true value of the proportions for 1997 and 1998 and for 2002 and 2003 are equal. The alternative hypothesis is that the former exceeds the latter. The test statistic takes account of the fact that in neither case is the true value of the proportion observed. Value of the test statistic, which is normally distributed, above 1.645 (1.282) indicates that there is a 95 (90) percent or more chance that in fact the true proportion in 200203 is smaller than in 1997-98.
} 
the case of construction services, the value of the test statistic exceeds 1.645 , thereby indicating a 95 percent or greater chance that in fact the true proportion of contracts awarded using nonLT methods in 2002-03 is smaller than in 1997-98. On the whole, as well, the finding in the bottom row of the final column of Table 1 supports the contention that the proportion of abovethe-threshold procurement contracts in Japan by number subject to internationally competitive bidding fell over time at the $10 \%$ significance level (but not at the $5 \%$ level). 
Table 1: Japanese services contracts by number

\begin{tabular}{|c|c|c|c|c|c|c|c|c|c|c|c|c|}
\hline I & II & III & IV & $\mathbf{V}$ & VI & VII & VIII & IX & $\mathbf{X}$ & XI & XII & XIII \\
\hline Services & $\sim \sim \sim$ & Avg. 1997-98 & 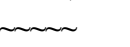 & $\sim \sim$ & Avg. 2002-03 & 3 & Avg. 1997-98 & Avg. 2002-03 & & Avg. 1997-98 & Avg. 2002-03 & \\
\hline Category & AT & Foreigners & Non-LT & AT & Foreigners & Non-LT & FP(\%) & FP(\%) & Test statistic & ICB(\%) & ICB(\%) & Test statistic \\
\hline 41 & 552.5 & 3 & 448.5 & 559 & 0.5 & 449.5 & 0.5 & 0.1 & 1.61 & 81.2 & 80.4 & 3.12 \\
\hline 42 & 14.5 & 0 & 3 & 53 & 0 & 15.5 & 0.0 & 0.0 & & 20.7 & 29.2 & -0.01 \\
\hline 51 & 0.5 & 0 & 0.5 & 6 & 0 & 5.5 & 0.0 & 0.0 & & 100.0 & 91.7 & -0.06 \\
\hline 52 & 0.5 & 0 & 0 & 0 & 0 & 0 & 0.0 & $\mathrm{np}$ & & 0.0 & $\mathrm{np}$ & \\
\hline 53 & 34 & 0 & 4.5 & 54.5 & 0 & 16.5 & 0.0 & 0.0 & & 13.2 & 30.3 & -0.01 \\
\hline 54 & 14 & 0 & 14 & 7 & 0 & 7 & 0.0 & 0.0 & & 100.0 & 100.0 & \\
\hline 55 & 0 & 0 & 0 & 0 & 0 & 0 & $\mathrm{np}$ & $\mathrm{np}$ & & $\mathrm{np}$ & $\mathrm{np}$ & \\
\hline 56 & 2 & 0 & 1 & 14.5 & 1 & 9 & 0.0 & 6.9 & 0.00 & 50.0 & 62.1 & 0.00 \\
\hline 57 & 8 & 0 & 6 & 26.5 & 0 & 9 & 0.0 & 0.0 & & 75.0 & 34.0 & 0.00 \\
\hline 58 & 0 & 0 & 0 & 0 & 0 & 0 & $\mathrm{np}$ & $\mathrm{np}$ & & $\mathrm{np}$ & $\mathrm{np}$ & \\
\hline 61 & 0 & 0 & 0 & 3.5 & 0 & 1.5 & np & 0.0 & & np & 42.9 & \\
\hline 62 & 0 & 0 & 0 & 1 & 0 & 1 & $\mathrm{np}$ & 0.0 & & np & 100.0 & \\
\hline 63 & 10 & 2 & 0 & 20 & 4 & 2 & 20.0 & 20.0 & 0.00 & 0.0 & 10.0 & 0.00 \\
\hline 64 & 0.5 & 0 & 0 & 0.5 & 0 & 0 & 0.0 & 0.0 & & 0.0 & 0.0 & \\
\hline 65 & 2 & 0 & 1 & 5 & 0 & 0 & 0.0 & 0.0 & & 50.0 & 0.0 & 0.00 \\
\hline 66 & 0 & 0 & 0 & 0 & 0 & 0 & $\mathrm{np}$ & $\mathrm{np}$ & & $\mathrm{np}$ & $\mathrm{np}$ & \\
\hline 67 & 7.5 & 0.5 & 0 & 33 & 2 & 15 & 6.7 & 6.1 & 0.00 & 0.0 & 45.5 & -0.03 \\
\hline 71 & 766 & 65 & 303 & 1370.5 & 83.5 & 548.5 & 8.5 & 6.1 & 0.05 & 39.6 & 40.0 & -1.07 \\
\hline 72 & 3.5 & 0 & 2.5 & 13.5 & 1 & 5.5 & 0.0 & 7.4 & 0.00 & 71.4 & 40.7 & 0.00 \\
\hline 73 & 220 & 2.5 & 34.5 & 136.5 & 1.5 & 48 & 1.1 & 1.1 & 0.00 & 15.7 & 35.2 & -0.06 \\
\hline 74 & 29 & 0 & 28.5 & 79 & 0 & 75.5 & 0.0 & 0.0 & & 98.3 & 95.6 & 0.01 \\
\hline 75 & 261 & 0 & 245.5 & 335 & 0 & 324.5 & 0.0 & 0.0 & & 94.1 & 96.9 & -0.07 \\
\hline 76 & 60 & 0 & 50 & 108 & 0 & 92 & 0.0 & 0.0 & & 83.3 & 85.2 & -0.05 \\
\hline 77 & 148.5 & 2 & 116.5 & 114 & 2.5 & 69.5 & 1.3 & 2.2 & 0.00 & 78.5 & 61.0 & 0.05 \\
\hline 78 & 46.5 & 0 & 42.5 & 67.5 & 0 & 58.5 & 0.0 & 0.0 & & 91.4 & 86.7 & -0.02 \\
\hline Total & 2180.5 & 75 & 1301.5 & 3007.5 & 96 & 1753.5 & 3.4 & 3.2 & 0.69 & 59.7 & 58.3 & 1.42 \\
\hline
\end{tabular}

Source: WTO, Committee on Government Procurement; own calculations

Note: (1) "np" denotes no AT procurement (2) Values exceeding 1.645 in columns X and XIII denote rejection of the null hypothesis (non-decline in foreign procurement and use of non-LT over time) at the 5\% level of significance (3) Data is averaged over 1997-98 and 2002-03 
Looking next at contract values (averaged over 1997-98 and 2002-03 and expressed in real terms using the US GDP Implicit Price Deflator) in Table 2, we see that Japanese services procurement fell by roughly 25\% from USD 14.8 bn to USD 11 bn over 1997-8, 2002-3. The share of foreign procurement dropped from 1.3 to $1.1 \%$, while the use of non-limited tendering fell from 71.3 to $69.4 \%$. Construction, followed by computer-related services, dominates services procurement in Japan, together accounting for $95 \%$ of all services contracts in value, but the average above-threshold values for both these services fell over time. Further, fewer of these services were awarded to foreign suppliers in 2002-03 than in 1997-98. On the other hand, the use of non-limited tendering increased slightly in the case of construction services but declined sharply for computer-related services, suggesting a net constriction in the market open to international competition.

\section{Table 2: Japanese services contracts by value}

\begin{tabular}{|c|c|c|c|c|c|c|c|c|}
\hline \multirow{3}{*}{$\begin{array}{c}\text { I } \\
\text { (Value real USD mn) } \\
\text { Services categories }\end{array}$} & II & III & IV & $\mathbf{V}$ & VI & VII & \multirow[t]{2}{*}{ VIII } & \multirow[t]{2}{*}{ IX } \\
\hline & 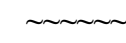 & vg. 1997-9 & 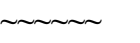 & 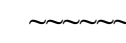 & vg. 2002-- & 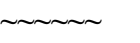 & & \\
\hline & AT & FP (\%) & ICB (\%) & AT & FP (\%) & ICB (\%) & UFP & UICB \\
\hline 41 & 12430.3 & 0.4 & 76.9 & 8638.4 & 0.0 & 81.3 & 2799.7 & -37834.9 \\
\hline 42 & 106.2 & 0.0 & 3.2 & 82.0 & 0.0 & 17.7 & 0.0 & -1196.2 \\
\hline 51 & 0.2 & 0.0 & 100.0 & 60.8 & 0.0 & 99.8 & 0.0 & 9.7 \\
\hline 52 & 0.2 & 0.0 & 0.0 & 0.0 & $\mathrm{np}$ & np & & \\
\hline 53 & 26.0 & 0.0 & 15.6 & 37.9 & 0.0 & 28.5 & 0.0 & -490.0 \\
\hline 54 & 19.8 & 0.0 & 100.0 & 8.9 & 0.0 & 100.0 & 0.0 & 0.0 \\
\hline 55 & 0.0 & $\mathrm{np}$ & $\mathrm{np}$ & 0.0 & $\mathrm{np}$ & $\mathrm{np}$ & & \\
\hline 56 & 1.0 & 0.0 & 50.3 & 11.4 & 6.4 & 72.3 & -73.3 & -252.0 \\
\hline 57 & 6.2 & 0.0 & 68.8 & 19.4 & 0.0 & 48.9 & 0.0 & 386.3 \\
\hline 58 & 0.0 & $\mathrm{np}$ & $\mathrm{np}$ & 0.0 & $\mathrm{np}$ & $\mathrm{np}$ & & \\
\hline 61 & 0.0 & 100.0 & 100.0 & 1.7 & 0.0 & 49.7 & 165.5 & 83.2 \\
\hline 62 & 0.0 & $\mathrm{np}$ & np & 0.4 & 0.0 & 100.0 & & \\
\hline 63 & 5.8 & 22.2 & 0.0 & 9.3 & 10.2 & 3.1 & 112.3 & -28.7 \\
\hline 64 & 0.3 & 0.0 & 0.2 & 0.3 & 0.0 & -256.9 & 0.0 & 82.3 \\
\hline 65 & 0.7 & 0.0 & 45.3 & 1.3 & 0.0 & 0.1 & 0.0 & 56.7 \\
\hline 66 & 0.0 & $\mathrm{np}$ & $\mathrm{np}$ & 0.0 & $\mathrm{np}$ & $\mathrm{np}$ & & \\
\hline 67 & 8.5 & 9.8 & -12.8 & 41.6 & 9.5 & 14.7 & 13.2 & -1141.2 \\
\hline 71 & 1811.0 & 8.1 & 40.2 & 1797.7 & 6.3 & 16.6 & 3182.3 & 42354.0 \\
\hline 72 & 1.5 & 0.0 & 79.6 & 9.9 & 3.5 & 16.8 & -34.3 & 619.8 \\
\hline 73 & 135.7 & 0.3 & 13.5 & 104.5 & 1.2 & 36.5 & -97.6 & -2399.9 \\
\hline 74 & 24.3 & 0.0 & 99.3 & 17.1 & 0.0 & 94.4 & 0.0 & 84.2 \\
\hline 75 & 135.3 & 0.0 & 94.8 & 108.4 & 0.0 & 92.8 & 0.0 & 220.0 \\
\hline 76 & 26.2 & 0.0 & 82.7 & 45.4 & 0.0 & 82.5 & 0.0 & 10.6 \\
\hline 77 & 102.6 & 2.2 & 69.1 & 60.1 & 4.6 & 57.5 & -143.7 & 696.2 \\
\hline 78 & 13.0 & 0.0 & 72.4 & 20.3 & 0.0 & 83.8 & 0.0 & -231.2 \\
\hline Total & 14854.8 & 1.3 & 71.3 & 11076.9 & 1.1 & 69.4 & 1960.8 & 21303.3 \\
\hline
\end{tabular}


Source: WTO, Committee on Government Procurement; own calculations

Note: (1) "np" denotes no AT procurement (2) Categories 41 and 71 reported large-value contracts

(3) Data is averaged over 1997-98 and 2002-03 (4) Contract values in SDR converted to real US dollar using the SDR-USD exchange rate and the US GDP Implicit Price Deflator

These declining metrics together translate into an unrealized foreign market access of USD 1.96 bn and a UICB worth USD 21.3 bn (reported in columns VIII and IX of Table 2). These are hugely significant magnitudes - for instance, had the shares of foreigner-won and non-LTawarded contracts in above-threshold contracts by value not declined over time, foreign services procurement in 2002-03 would have been more than 15 times higher (ratio of total UFP to total actual FP in 2002-03) and the value of contracts open to ICB would have been almost three times larger (ratio of total UICB to total actual ICB in 2002-03).

\subsection{Swiss services procurement}

In the case of Switzerland, considering the year 2003 to be a statistical outlier, we conduct analogous analyses comparing Swiss submissions on services procurement averaged over 1996-97 and 2001-02. Data on Swiss contracts numbers is reported in Table 3 and on contracts value in Table 4. We consider both non-construction (categories 1-18) and construction (categories 1-8) services included by Switzerland in Annexes 4 and 5 of Appendix 1 of the GPA; the list is provided in Annex Table 3 of this paper.

From Table 3 we see that in 1996-97, there were 264.5 services contracts awarded on average by the Swiss above threshold, of which $9.3 \%$ were awarded to foreign firms. $66.7 \%$ of these contracts did not involve the use of limited tendering procedures. In 2001-02, the average number of contracts had risen to 352.5 , but the percentage awarded to foreigners had fallen to $4.5 \%$, and the percentage of these contracts that did not employ limited tendering was also marginally lower at $66.5 \%$. Ceteris paribus, therefore, a la Japan, these findings are not indicative of greater foreign access to Swiss services procurement. 
Supporting this contention, the test statistic (calculated once again by weighting the contract numbers by their respective values as in the case of Japan) in the bottom line under column X of Table 3 takes the value of 3.18, thereby suggesting that the true proportion of contracts awarded to foreign firms was lower in 2001-02 than in 1996-97 (the same result holds true for total non-construction services). On the other hand, the test statistic in the bottom line of column XIII does not point to statistically significant reductions in the proportion of above threshold contacts awarded using non-LT methods, though category 14 (consulting and technical services) and non-construction services on the whole do actually suggest such reductions (at the 5 and 10\% levels of significance, respectively). 


\section{Table 3: Swiss services contracts by number}

\begin{tabular}{|c|c|c|c|c|c|c|c|c|c|c|c|c|}
\hline I & II & III & IV & $\mathbf{V}$ & VI & VII & VIII & IX & $\mathbf{X}$ & XI & XII & XIII \\
\hline & $\sim$ & Avg. 1996-9 & 7 & $\sim$ & Avg. 2001-02 & $2 \sim \sim \sim$ & Avg. 1996-97 & Avg. 2001-02 & & Avg. 1996-97 & Avg. 2001-02 & \\
\hline Categories & AT & Foreigners & Non-LT & AT & Foreigners & Non-LT & FP (\%) & FP (\%) & Test statistic & ICB (\%) & ICB (\%) & Test statistic \\
\hline 1 & 34 & 0.5 & 12.5 & 30.5 & 0.5 & 15.5 & 1.5 & 1.6 & 0.02 & 36.8 & 50.8 & 0.08 \\
\hline 2 & 9 & 2.5 & 8.5 & 1 & 0 & 0.5 & 27.8 & 0.0 & 0.12 & 94.4 & 50.0 & 0.12 \\
\hline 3 & 1.5 & 0.5 & 1.5 & 0 & 0 & -1 & 33.3 & 0.0 & & 100.0 & 0.0 & \\
\hline 4 & 0 & 0 & 0 & 0 & 0 & -1 & 0.0 & 0.0 & & 0.0 & 0.0 & \\
\hline 5 & 0.5 & 0 & 0.5 & 2.5 & 0.5 & 0.5 & 0.0 & 20.0 & -0.01 & 100.0 & 20.0 & -0.01 \\
\hline 6 & 0 & 0 & 0 & 0 & 0 & -0.5 & 0.0 & 0.0 & & 0.0 & 0.0 & \\
\hline 7 & 33 & 0.5 & 20.5 & 95.5 & 4 & 58.5 & 1.5 & 4.2 & -0.20 & 62.1 & 61.3 & -0.49 \\
\hline 8 & 0 & 0 & 0 & 1.5 & 0 & 1.5 & 0.0 & 0.0 & & 0.0 & 100.0 & \\
\hline 9 & 1.5 & 0 & 1.5 & 5 & 0 & 3 & 0.0 & 0.0 & & 100.0 & 60.0 & 0.06 \\
\hline 10 & 5 & 0.5 & 1 & 10 & 0.5 & 2.5 & 10.0 & 5.0 & 0.00 & 20.0 & 25.0 & -0.01 \\
\hline 11 & 14.5 & 2.5 & 9.5 & 0 & 0 & 0 & 17.2 & 0.0 & & 65.5 & 0.0 & \\
\hline 12 & 14 & 1 & 0.5 & 20.5 & 1 & 16 & 7.1 & 4.9 & -0.18 & 3.6 & 78.0 & -2.44 \\
\hline 13 & 0 & 0 & 0 & 1.5 & 0 & 0 & 0.0 & 0.0 & & 0.0 & 0.0 & \\
\hline 14 & 119 & 11 & 88 & 132.5 & 8.5 & 96.5 & 9.2 & 6.4 & 1.23 & 73.9 & 72.8 & 3.93 \\
\hline 15 & 1.5 & 0 & 1.5 & 10.5 & 0 & 2.5 & 0.0 & 0.0 & & 100.0 & 23.8 & -0.03 \\
\hline 16 & 0.5 & 0 & 0.5 & 0.5 & 0 & 0.5 & 0.0 & 0.0 & & 100.0 & 100.0 & \\
\hline 17 & 0 & 0 & 0 & 5.5 & 0.5 & 4 & 0.0 & 9.1 & & 0.0 & 72.7 & \\
\hline 18 & 0 & 0 & 0 & 0 & 0 & 0 & 0.0 & 0.0 & & 0.0 & 0.0 & \\
\hline Non-construction & 234 & 19 & 146 & 317 & 15.5 & 199 & 8.1 & 4.9 & 2.20 & 62.4 & 62.8 & 1.49 \\
\hline 1 & 7.5 & 0 & 7.5 & 4 & 0 & 4 & 0.0 & 0.0 & & 100.0 & 100.0 & \\
\hline 2 & 5 & 5 & 5 & 11 & 0.5 & 11 & 100.0 & 4.5 & 0.30 & 100.0 & 100.0 & \\
\hline 3 & 0 & 0 & 0 & 0 & 0 & 0 & 0.0 & 0.0 & & 0.0 & 0.0 & \\
\hline 4 & 0 & 0 & 0 & 0 & 0 & 0 & 0.0 & 0.0 & & 0.0 & 0.0 & \\
\hline 5 & 2 & 0.5 & 2 & 0 & 0 & 0 & 25.0 & 0.0 & & 100.0 & 0.0 & \\
\hline 6 & 8 & 0 & 8 & 5 & 0 & 5 & 0.0 & 0.0 & & 100.0 & 100.0 & \\
\hline 7 & 8 & 0 & 8 & 3 & 0 & 3 & 0.0 & 0.0 & & 100.0 & 100.0 & \\
\hline 8 & 0 & 0 & 0 & 12.5 & 0 & 12.5 & 0.0 & 0.0 & & 0.0 & 100.0 & \\
\hline Construction & 30.5 & 5.5 & 30.5 & 35.5 & 0.5 & 35.5 & 18.0 & 1.4 & 0.22 & 100.0 & 100.0 & \\
\hline All services & 264.5 & 24.5 & 176.5 & 352.5 & 16 & 234.5 & 9.3 & 4.5 & 3.18 & 66.7 & 66.5 & 0.07 \\
\hline
\end{tabular}

Source: WTO, Committee on Government Procurement; own calculations

Note: (1) "np" denotes no AT procurement (2) Values exceeding 1.645 in columns X and XIII denote rejection of the null hypothesis (non-decline in foreign procurement and use of non-LT over time) at the 5\% level of significance (3) Data is averaged over 1996-97 and 2001-02 
In terms of contract values reported in Table 4 (averaged over 1996-97 and 2001-02 and expressed in real terms using the US GDP Implicit Price Deflator), average Swiss services procurement (excluding that in construction) rose by nearly half from USD $204 \mathrm{mn}$ to USD 305 mn over 1996-7, 2001-2, while construction services witnessed a more than three-fold increase from USD $16.5 \mathrm{mn}$ to USD $53.9 \mathrm{mn}$. Within non-construction services, the share of foreign procurement in services fell from 5.2 to $4 \%$ while the use of non-limited tendering fell marginally from 78 to $77.5 \%$. Construction services, driven primarily by general building construction work (category 2), witnessed a huge fall in foreign procurement from 23.3 to 3.6\%. Data also suggests that the Swiss government did not resort to limited tendering practices in the award of construction services contracts. On the whole, the share of foreign procurement in services fell from 6.6 to 3.9\% while the use of non-limited tendering increased from 80 to $81 \%$. Technical, scientific and consulting services (categories 12 and 14), followed by computer-related (category 7), construction and repair services (category 1), dominate Swiss services procurement, accounting for more than $90 \%$ of all services contracts in value terms, and barring repair services (category 1), the average above-threshold procurement for the other major categories increased over time. Foreign procurement share in these services fell sharply for technical, scientific and consulting (category 12) and construction services while the use of non-limited tendering fell in the case of technical, scientific and consulting services (category 14).

The results from counterfactual analysis in the case of Swiss services procurement, reported in Columns VIII and IX of Table 4, translate into an unrealized foreign market access of USD $953 \mathrm{mn}$, a value that is even more significant in terms of magnitude than the comparable figure for Japan - had the shares of foreigner-won above-threshold contracts by value not declined over time, foreign services procurement in 2001-02 would have been nearly 68 times higher (ratio of total actual UFP to total actual FP in 2001-02)! On the other hand, UICB is $-418.5 \mathrm{mn}$, which suggests that the de jure openness increased. However, this result emanates from the Swiss government's non-use of limited tendering in awarding construction services contracts. If we consider only non-construction services, UICB is USD $176.5 \mathrm{mn}$ - the value of nonconstruction services contracts open to ICB would have been $75 \%$ more (ratio of total actual 
UICB in non-construction to total actual ICB in non-construction in 2001-02) had the use of non-LT in these services not declined over 1996-97, 2001-02.

\section{Table 4: Swiss services contracts by value}

\begin{tabular}{|c|c|c|c|c|c|c|c|c|}
\hline I & II & III & IV & $\mathbf{V}$ & VI & VII & VIII & IX \\
\hline (Value real USD mn) & \multicolumn{3}{|c|}{$\sim \sim$ Avg. 1996-97 } & \multicolumn{3}{|c|}{$\sim \sim \sim$ Avg. 2001-02 } & & \\
\hline Categories & AT & FP $(\%)$ & ICB (\%) & AT & FP $(\%)$ & ICB (\%) & UFP & UICB \\
\hline 1 & 20.7 & 0.5 & 12.8 & 19.6 & 3.1 & 44.8 & -50.6 & -627.2 \\
\hline 2 & 9.8 & 7.8 & 95.8 & 0.3 & 0.0 & 50.6 & 2.0 & 11.7 \\
\hline 3 & 1.5 & 6.1 & 100.0 & 0.0 & $\mathrm{np}$ & np & & \\
\hline 4 & 0.0 & $\mathrm{np}$ & $\mathrm{np}$ & 0.0 & np & np & & \\
\hline 5 & 0.1 & 0.0 & 100.0 & 2.8 & 4.2 & -56.7 & -12.0 & 445.8 \\
\hline 6 & 0.0 & $\mathrm{np}$ & $\mathrm{np}$ & 0.0 & $\mathrm{np}$ & $\mathrm{np}$ & & \\
\hline 7 & 15.2 & 0.7 & 46.8 & 44.9 & 8.8 & 61.7 & -366.7 & -665.8 \\
\hline 8 & 0.0 & $\mathrm{np}$ & np & 0.3 & 0.0 & 100.0 & & \\
\hline 9 & 3.4 & 0.0 & 100.0 & 3.2 & 0.0 & 86.0 & 0.0 & 45.4 \\
\hline 10 & 1.4 & 7.4 & 13.9 & 4.4 & 13.5 & 45.4 & -27.2 & -138.8 \\
\hline 11 & 20.5 & 19.6 & 76.2 & 0.0 & $\mathrm{np}$ & np & & \\
\hline 12 & 1.6 & 82.6 & 56.4 & 82.5 & 0.7 & 98.8 & 6755.2 & -3498.1 \\
\hline 13 & 0.0 & $\mathrm{np}$ & np & 0.7 & 0.0 & -12.9 & & \\
\hline 14 & 129.5 & 3.2 & 91.2 & 137.4 & 4.5 & 84.3 & -175.3 & 950.4 \\
\hline 15 & 0.4 & 0.0 & 100.0 & 6.8 & 0.0 & 3.0 & 0.0 & 656.6 \\
\hline 16 & 0.2 & 0.0 & 100.0 & 0.1 & 0.0 & 100.0 & 0.0 & 0.0 \\
\hline 17 & 0.0 & $\mathrm{np}$ & $\mathrm{np}$ & 2.0 & 6.8 & 74.2 & & \\
\hline 18 & 0.0 & $\mathrm{np}$ & np & 0.0 & $\mathrm{np}$ & $\mathrm{np}$ & & \\
\hline Total non-construction & 204.4 & 5.2 & 78.1 & 305.1 & 4.0 & 77.5 & 379.5 & 176.5 \\
\hline 1 & 0.6 & 0.0 & 100.0 & 19.1 & 0.0 & 100.0 & 0.0 & 0.0 \\
\hline 2 & 3.7 & 100.0 & 100.0 & 27.2 & 7.1 & 100.0 & 2528.0 & 0.0 \\
\hline 3 & 0.0 & $\mathrm{np}$ & $\mathrm{np}$ & 0.0 & $\mathrm{np}$ & $\mathrm{np}$ & & \\
\hline 4 & 0.0 & $\mathrm{np}$ & np & 0.0 & np & $\mathrm{np}$ & & \\
\hline 5 & 4.3 & 3.8 & 100.0 & 0.0 & $\mathrm{np}$ & $\mathrm{np}$ & & \\
\hline 6 & 2.0 & 0.0 & 100.0 & 1.9 & 0.0 & 100.0 & 0.0 & 0.0 \\
\hline 7 & 5.8 & 0.0 & 100.0 & 0.3 & 0.0 & 100.0 & 0.0 & 0.0 \\
\hline 8 & 0.0 & $\mathrm{np}$ & $\mathrm{np}$ & 5.4 & 0.0 & 100.0 & & \\
\hline Total construction & 16.5 & 23.3 & 100.0 & 53.9 & 3.6 & 100.0 & 1065.7 & noLT \\
\hline All services & 220.8 & 6.6 & 79.7 & 359.0 & 3.9 & 80.9 & 953.1 & -418.5 \\
\hline
\end{tabular}

Source: WTO, Committee on Government Procurement; own calculations

Note: (1) "np" denotes no AT procurement and "no LT" denotes non-use of limited tendering

(2) Categories 1, 7, 12 and 14 among non-construction and categories 1and 2 among construction services reported large-value contracts (3) Data is averaged over 1996-97 and 2001-02

(4) Contract values in SDR converted to real US dollar using the SDR-USD exchange rate and the US GDP Implicit Price Deflator 


\subsection{Private-public purchase differentials}

Finally, results from the counterfactual analysis against the private sector for both Japan and Switzerland are reported in Table 5. Data on sectoral output and imports for the two countries is taken from the OECD's STAN database for structural analysis and trade in services by service category, respectively. Unfortunately, sector-specific data on imports and gross output is not available for all services categories; hence, the individual services categories for the two countries have been aggregated into broader categories (the composition is shown in brackets against each category in Table 5) to enable better analysis. Even then, the absence of import data for Swiss construction and computer-related services over our sample period meant that the counterfactuals even for these broad categories could not be calculated in the case of Switzerland.

\section{Table 5: Private-public purchase differentials}

\begin{tabular}{|c|c|c|c|c|c|c|c|}
\hline \multicolumn{8}{|c|}{ Japan (values in real USD mn) } \\
\hline Categories & 1997 & 1998 & 1999 & 2000 & 2001 & 2002 & 2003 \\
\hline Construction (41) & 149.0 & 292.9 & 123.2 & 122.3 & 118.8 & 149.6 & 147.7 \\
\hline Other business $(42,72-73,75-78)$ & 33.3 & 57.6 & 25.5 & 25.5 & 30.7 & 24.7 & 31.8 \\
\hline Transportation (53-57) & 10.4 & 14.3 & 9.3 & 14.9 & 16.2 & 21.4 & 22.0 \\
\hline Communication $(58,61-65)$ & -0.6 & -1.5 & -1.2 & -0.1 & -0.2 & -0.7 & -0.8 \\
\hline Computer-related $(66-67,71)$ & 132.9 & -12.5 & 1.0 & 5.7 & 1.4 & -33.6 & -22.5 \\
\hline Total & 325.0 & 350.7 & 157.7 & 168.3 & 166.8 & 161.5 & 178.1 \\
\hline \multicolumn{8}{|c|}{ Switzerland (values in real USD mn) } \\
\hline Categories & 1997 & 1998 & 1999 & 2000 & 2001 & 2002 & 2003 \\
\hline Transportation (2-4) & 9.0 & 3.1 & 1.9 & 1.8 & 0.0 & 0.2 & 0.8 \\
\hline Communication (5) & 0.05 & 1.1 & 1.2 & 0.5 & 0.4 & 0.6 & 0.5 \\
\hline Financial (6) & 0.00 & 0.00 & 0.04 & 0.00 & 0.00 & 0.00 & 0.00 \\
\hline Other business $(1,8-18)$ & -4.2 & -8.3 & -7.6 & -7.7 & -9.1 & -4.2 & -129.0 \\
\hline Total & 4.8 & -4.0 & -4.5 & -5.5 & -8.7 & -3.4 & -127.7 \\
\hline
\end{tabular}

Source: WTO, Committee on Government Procurement; OECD Stats Online; own calculations

Note: (1) Import data was not available for construction and computer-related services in the case of

Switzerland; hence, the counterfactuals are missing for these categories (2) Financial services are not included by Japan in Annexes 4 and 5 of Appendix 1 of the GPA (3) The numbers in brackets against each broad 
category indicate the individual services categories listed in Annex Tables 2 and 3 that were aggregated to form that broad category

Table 5 reveals that Japanese services in these categories, primarily construction, have seen large private-public purchase differentials over time, a finding that is consistent with Baldwin's $(1970,1984)$ "neutrality proposition" and the home-bias in Japanese services procurement. The differentials were USD $325 \mathrm{mn}$ in 1997 but declined to USD $178 \mathrm{mn}$ in 2003 largely on account of rising public purchase of computer-related services from foreign suppliers, a category which therefore showed negative differentials in 1998, 2002 and 2003. The differentials were always positive in the case of construction, other business and transportation services and also showed a more than two-fold increase for transportation services. Thus, had the private sector been making government procurement decisions in these services, they would have purchased more from foreign suppliers than the government actually did. Communication services, on the other hand, always report a negative differential, which suggests that the Japanese government may not have been favouring domestic firms in the purchase of these services.

Absence of comparable data for a broader range of Swiss services renders a similar analysis more suggestive than conclusive. Swiss services see a positive but declining differential for transportation services (suggesting reduced importance of the home-bias), a zero differential for financial services (absence of above-threshold procurement) except in 1999 when the differential was positive (suggesting a home-bias) and a positive and nearly constant differential for communication services over 2000-03 (suggesting no change over time in the importance of the home-bias). The differential for other business services is always negative (suggesting no home-bias) but jumps to USD -129 $\mathrm{mn}$ in 2003, a result that supports the choice of this year as a statistical outlier in the case of Switzerland.

On the whole, results from this counterfactual analysis suggest that at least the Japanese government has not been purchasing as much from abroad as it's private sector is importing from the rest of the world for the same services categories. These results are thus consistent with those from the preceding analyses on the home-bias in Japanese services procurement patterns. 


\section{Conclusion}

The results from the analyses undertaken in this paper suggest that the URGPA has not really been effective in increasing or even sustaining market access for foreigners in the procurement markets of two of its signatories - Japan and Switzerland. We have examined data from two of the 40 Contracting Parties to the GPA that have submitted detailed data in a form amenable to our statistical analysis; hence, the results are specific to these countries. This said, the results can be generalized to the extent that they point in the same direction, suggesting a home-bias in the award of government services contracts.

A careful reading of the results further suggests that this may be due to a combination of incomplete/ineffective provisions and a weak enforcement mechanism. For instance, despite the requirements of Article XIX:5, only half of the 40 Contracting Parties have submitted procurement data consistently over time to the WTO, which points to weak enforcement and in turn, could be due to the absence of any punitive action or public censure for non-submission. This said, one needs to exercise some restraint in the interpretation of the results in this paper given that at least one of the countries studied (Japan) underwent stagnation and recession for much of the period since the Uruguay Round and this may have influenced that government's procurement decisions. Even so, there is enough argument for addressing the loopholes in the GPA (too many exclusions/exemptions allowed; non-price discrimination is allowed while more efficient price preferences are explicitly banned) and for giving it more teeth (public censure for non-adherence to data reporting commitments; provision of incentives to whistleblowers revealing corruption in procurement). The WTO's Trade Policy Review Mechanism could also work through peer-pressure by highlighting non-compliance with Article XIX: 5 and/or pointing out distinct breaks in past patterns of public procurement that signal a move towards discrimination.

Finally, while the evidence reported in this paper may be more suggestive, the finding that the GPA did not increase ex-post foreign market access in services in these two governments' public purchases is undeniably conclusive. Furthermore, if this result were repeated all over, then it must reflect home biases in government procurement because not every country can 
have greater efficiency at home. The analysis in this paper is thus similar to the analyses examining residuals from gravity models to illustrate protection in goods markets. In a similar vein, our results do suggest discrimination against foreign suppliers in the government procurement markets for services in these two countries. 


\section{Bibliography}

Baldwin, R.E. (1970). 'Nontariff Distortions of International Trade.' Brookings Institution, Washington, DC.

Baldwin, R.E. (1984). 'Trade policies in developed countries,' in Jones, R., Kenen, P. (Eds.), Handbook of International Economics, North-Holland, Amsterdam.

Branco, Fernando. (1994). 'Favouring Domestic Firms in Procurement Contracts.' Journal of International Economics, No. 37, pp 65-80.

Breton, Albert \& Pierre Salmon (1995). 'Are Discriminatory Procurement Policies Motivated by Protectionism?’ Kyklos, 49: 47-68.

Chen, Xiangqun (1995). 'Directing Government Procurement as an Incentive of Production.' Journal of Economic Integration, 10: 130-40.

Deltas, George \& Simon Evenett (1997). 'Quantitative Estimates of the Effects of Preference Policies' in Bernard Hoekman \& Petros Mavroidis ed. Law and Policy in Public Purchasing: The WTO Agreement on Government Procurement, University of Michigan Press.

Evenett, Simon J. (2000). 'Reforming the Government Procurement Agreement: Promote Transparency then Non-discrimination,' The World Bank, the Brookings Institutions and CEPR, November.

Evenett, Simon \& Anirudh Shingal (2006). 'Monitoring Implementation: Japan and the WTO Agreement on Government Procurement,' in Economic Development \& Multilateral Trade Cooperation, Oxford University Press and the World Bank. 
Laffont, J.J \& Jean Tirole (1991).'Auction Design and Favouritism.' International Journal of Industrial Organization, 9: 9-42.

McAfee, R. Preston \& John McMillan (1989). 'Government Procurement and International Trade.' Journal of International Economics, 26: 291-308.

Miyagiwa, K. (1991). 'Oligopoly and discriminatory government procurement policy.' American Economic Review 81, 1321-1328.

OECD (2002). 'The Size of Government Procurement Markets,' Journal of Budgeting 1(4).

Rothenberg, Julio (1993). "Comment" in Jim Leitzel \& Jean Tirole eds. Incentives in Procurement Contracting. Boulder: Westview Press.

Shingal, Anirudh (2002). 'The Agreement on Government Procurement: An Analysis of Submissions made by Japan,' unpublished Masters Thesis, World Trade Institute, Berne.

Transparency International (1997). 'The TI Source Book: Applying the Framework' (www.transparency.de)

World Bank (1994). 'Rehabilitation Loan: Pre-Identified Import Component Distribution Monitoring Report,' December 9, mimeo. 


\title{
Annex Table 1: Statistical submissions made to the Committee on Government Procurement
}

\author{
Year Reporting Countries \\ 2009 Hong Kong, Norway \\ 2008 Hong Kong, Japan, Norway \& USA \\ 2007 Hong Kong, Japan, Norway \& USA \\ 2006 Hong Kong, Japan, Norway \\ 2005 Hong Kong, Norway \& USA \\ 2004 Hong Kong, Japan \\ 2003 Canada, Hong Kong, Japan, Norway \& Switzerland \\ 2002 Canada, EC, Hong Kong, Japan, Korea, Norway \& Switzerland \& USA \\ 2001 Canada, EC, Hong Kong, Japan, Norway \& Switzerland \& USA \\ 2000 Canada, EC, Hong Kong, Japan, Norway \& Switzerland \& USA \\ 1999 Canada, EC, Hong Kong, Japan, Norway, Switzerland \& USA \\ 1998 Canada, EC, Hong Kong, Japan, Norway, Switzerland \& USA \\ 1997 Canada, EC, Hong Kong, Japan, Norway, Switzerland \& USA \\ 1996 Canada, EC, Norway, Switzerland \& USA \\ 1995 Hong Kong, Norway \& Switzerland \\ 1994 Austria, Finland, Hong Kong, Norway, Singapore, Sweden \& Switzerland \\ 1993 Austria, Canada, Finland, Hong Kong, Japan, Norway, Singapore, Sweden, Switzerland \& \\ USA \\ 1992 Austria, Canada, EC, Finland, Hong Kong, Israel, Japan, Norway, Singapore, Sweden \& \\ USA \\ 1991 \\ Austria, Canada, Finland, Hong Kong, Israel, Japan, Norway, Singapore, Sweden, \\ Switzerland \& USA \\ 1990 \\ Austria, Canada, EC, Finland, Hong Kong, Israel, Norway, Singapore, Sweden, \\ Switzerland \& USA \\ 1989 Canada, Finland, Hong Kong, Israel, Norway, Singapore, Sweden, Switzerland \& USA \\ 1988 Canada, Finland, Hong Kong, Israel, Norway, Singapore, Sweden, Switzerland \& USA \\ 1987 Canada, Finland, Hong Kong, Israel, Norway, Singapore, Sweden, Switzerland \& USA \\ 1986 Canada, Finland, Hong Kong, Israel, Norway, Singapore, Sweden, Switzerland \& USA \\ 1985 Austria, Canada, EC, Finland, Israel, Japan, Norway, Singapore, Sweden \& Switzerland
}

Source: WTO, Statistical submissions made to the Committee on Government Procurement, 1985-2009 
Annex Table 2: List of services procured by the Japanese

$\begin{array}{ccl}\text { Japanese Classification } & \text { CPC Code } & \text { Services Category } \\ 41 & 51 & \text { Construction work } \\ 42 & 867 & \text { Architectural, engineering \& other technical } \\ 51 & 6112 & \text { Maintenance \& repair (motor vehicles) } \\ 52 & 6122 & \text { Maintenance \& repair (motorcycles \& snowmobiles) } \\ 53 & 712 & \text { Other land transport } \\ 54 & 7213 & \text { Rental (sea-going vessels) } \\ 55 & 7223 & \text { Rental (non-sea-going vessels) } \\ 56 & 73 & \text { Air transport } \\ 57 & 748 & \text { Freight transport agency } \\ 58 & 7512 & \text { Courier } \\ 61 & 7523 & \text { Electronic mail } \\ 62 & 7521 & \text { Voice mail } \\ 63 & 7523 & \text { On-line info \& database retrieval } \\ 64 & 7523 & \text { Electronic data interchange (EDI) } \\ 65 & 7529 & \text { Enhanced fax } \\ 66 & 7523 & \text { Code and protocol conversion } \\ 67 & 7523 & \text { On-line info \&/or data processing } \\ 71 & 84 & \text { Computer \& related } \\ 72 & 864 & \text { Market research \& pub opinion polling } \\ 73 & 871 & \text { Advertising } \\ 74 & 87304 & \text { Armoured car } \\ 75 & 874 & \text { Building-cleaning } \\ 76 & 88442 & \text { Publishing \& printing } \\ 77 & \text { Repair (metal products \& machinery) } \\ 78 & \text { Sewage \& refuse disposal, sanitation \& other EP }\end{array}$

Source: WTO, Committee on Government Procurement; GATS, Central Product Classification 


\section{Annex Table 3: List of services procured by the Swiss}

$\begin{array}{cc}\begin{array}{c}\text { Swiss } \\ \text { Classification } \\ 1\end{array} & \text { CPC } \\ 2 & 712(\text { excd. } 71235), 7512,87304 \\ 3 & 73(\text { excd. } 7321) \\ 4 & 71235,7321 \\ 5 & 752(\text { excd. } 7524,7525,7526)\end{array}$

6

$811,812,814$

7

8

9

10

11

12

13

$$
14
$$

Construction services

$\begin{array}{ll}1 & 511 \\ 2 & 512 \\ 3 & 513 \\ 4 & 514 \\ 5 & 515 \\ 6 & 516 \\ 7 & 517 \\ 8 & 518\end{array}$

84
862
864
865,866
867

$874,82201-82206$

88442

94

\section{Services Descriptions}

Discussion to the wide direction (discussion, inspection, repairs)

Land transportation, including the transportation of money and the mail services, except the postal traffic and rail transportation

Air transportation: Transportation of travellers and of merchandise, except the transportation of courier

Transportation of mail by land or by airplane (except rail transportation)

Telecommunications (except the services of vocal telephony, of telex, of radio telephony, of radio-messaging and of telecommunications by satellite)

Services regarding assurance and bank services, except the financial services relating to the transmission, to the sale, to the purchase or to the transfer of titles or of other financial instruments, as well as services furnished by central banks

Computer and related services

Accounting, auditing and book-keeping services

Market and public-opinion polling services

Management consulting and related services

Architecture, urban installation and environmental architecture

Consulting and technical services, technical integrated services, relevant scientific and technical consulting, technical essays and analyses of construction projects

Works of study (auction of identical markets to several contractors to obtain different suggestions of solutions)

Consulting and technical services, technical integrated services, relevant scientific and technical consulting, technical essays and analyses not concerning construction projects

Advertising, information and public relations services

Cleanings of buildings and property management services

Edition and impression services

Sewage and refuse disposal, sanitation and analogous services

Preparation of the sites and work-sites of construction

Construction of buildings

Construction of civil works

Assembly and construction of prefabricated works

Works of specialized businesses of construction

Putting installations

Secondary work and building finishing

Housing and credit lease concerning equipments of construction or of demolition, personnel works

Source: WTO, Committee on Government Procurement; GATS, Central Product Classification

Note: The table has been translated into English from French 